\title{
The blood-storing ability of the spleen
}

\section{Ion Udroiu}

\begin{abstract}
In some mammalian species, pronounced muscularization together with increased spleen dimension allows this organ to store blood, releasing it in case of need. This is possible because of the large volume occupied by the cords of the red pulp and the richness in muscle cells of the capsule and trabeculae. Ungulates (excluding Cetaceans and Sirenians), Carnivores and Edentates show this splenic type. In other mammals, this organ do not store blood either because their different ecology or because this task is performed elsewhere in the body.
\end{abstract}

KEY WORDS: spleen, storage, morphology, evolution.

Ion Udroiu, [ion.udroiu@uniromal.it], Dipartimento di Biologia Animale e dell'Uomo, Università “La Sapienza”, 00161 Roma, Italy.

\section{Способность селезенки запасать кровь}

\section{И. Удройю}

РЕЗЮМЕ. У некоторых видов млекопитающих выраженная мускуляризация вместе с увеличенным размером селезенки позволяет этому органу запасать кровь, выпуская ее в случае потребности. Это возможно из-за большого объема, занятого тяжами красной пульпы и обилия мышечных клеток в оболочке и перегородках. Такой тип селезенки отмечен у копытных (исключая китообразных и сирен), хищных и неполнозубых. У других млекопитающих этот орган не накапливает кровь - или потому что они имеют экологические отличия, или потому что эту роль играет какой-нибудь другой орган.

КЛЮЧЕВЫЕ СЛОВА: селезенка, хранение, морфология, эволюция.

\section{Introduction}

The spleen shows several morphological types, depending on the relative importance of the different functions that reside in it. Among vertebrates, the mammals own the highest level of specialization of this organ. The mammalian spleen is composed by the capsule-trabecular system and by the parenchyma. The capsule is composed of collagen, elastic fibers and little smooth muscle cells; from it, the trabeculae (consisting of a dense fibrous connective tissue, composed of numerous collagen fibers and fibroblasts) depart inward. The parenchyma is composed of the red and the white pulp. The latter is almost the same in all mammalian species. In the white pulp, the arteries are surrounded by the PeriArterial Lymphoid Sheaths (PALS, rich in T-lymphocytes), which may contain lymphatic nodules (rich in B-lymphocytes). The white pulp is surrounded by the Marginal Zone, which is encircled by the red pulp. The red pulp consists of venous vessels and splenic cords (Billroth's cords). The pulp cords are considered cavernous vascular spaces, as they collect arterial blood and convey it to the venous vessels. They consist of a spongy mass of cells, mainly macrophages, held in by a reticular meshwork. The meshwork shows an enormous contact surface and its great section determines a low shear rate. Therefore, the erythrocytes move slower than plasma (Groom et al., 1991). Furthermore, the plasmatic component is separated from the cellular component by contraction of the splenic vein and drained by the lymphatic vessels. This explains the high hematocrit values found in the spleen. This peculiar feature allows the filtrative function of the spleen, but is also useful in some species to magnify the blood-storing properties.

The carnivoran spleen. The morphology of the spleen has been studied in Felis silvestris (Seki \& Abe, 1985), Panthera leo (Tischendorf, 1956), Canis lupus (Seki \& Abe, 1985; Alexandre-Pires et al., 2003), Ursus thibetanus (Zhang et al., 1997), Procyon lotor (Hayes \& Eglitis, 1967), Mustelidae (Abe et al., 1989; Hataba \& Suzuki, 1989) and Pinnipedia (Blessing et al., 1972; Schumacher \& Welsch, 1987; Cabanac et al., 1999; Stewardson et al., 1999).

Carnivora own high relative splenic weight. Moreover, they show an accentuated muscularization (capsule and trabeculae rich in smooth muscle cells) and consequent contractility. Therefore, this organ is able to store and release blood. Within the red pulp, which in this Order is the major part of the organ, the cords show a vast extension. Inside these, a great quantity of blood is retained. If needed, as in case of intensive stress, hypoxia or hemorrhage, the blood is pushed into the circulation by the contraction of the muscular capsule 


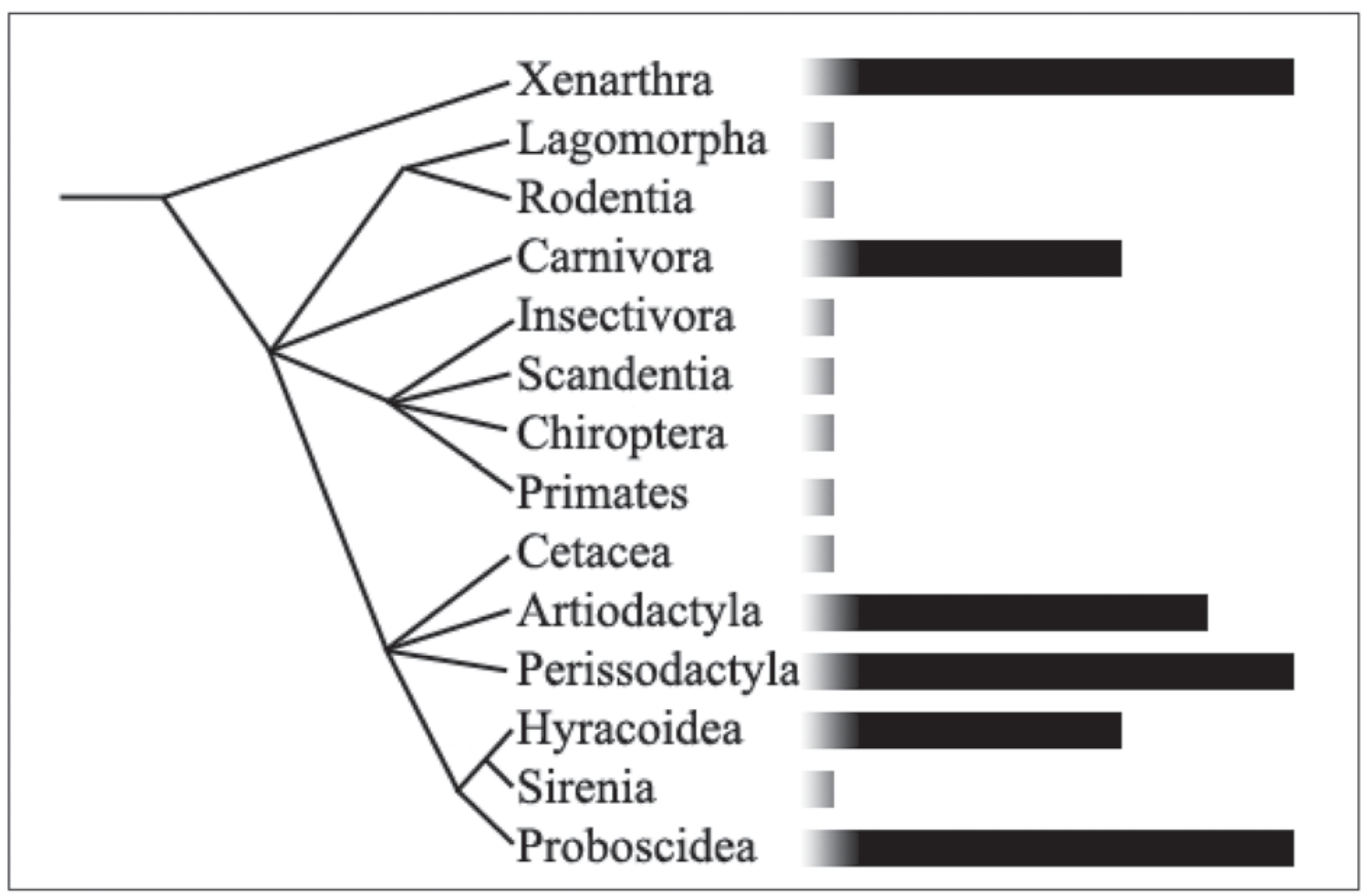

Figure 1. The phylogenetic tree of Placentalia (according to McKenna \& Bell, 1997). Bar length indicates the specialization of the blood-storing properties of the spleen.

and the trabeculae. This contraction also determines the canalization of the blood stream; this, in facts, does not disperse in the wide, dilated splenic cords. Instead, it runs through short, narrow channels and flows directly to the venous vessels.

Actually, in every species the spleen may store some blood. For example, this organ acts as a reservoir of platelets in several species, including man. However, the amount of erythrocytes that can be accumulated in the spleens of Monotremata, Marsupialia, Insectivora, Rodentia, Lagomorpha, Primates, Sirenia and Cetacea is really negligible. On the contrary, in the "storage" spleen of Carnivores, nearly $30 \%$ of the total blood volume can be retained in the red pulp, reaching higher values in seals.

The ungulate spleen. Apart from the external gross morphology, the histology and function of the equine spleen is very similar to that of the cat, although the storing capacity is greater (Tablin \& Weiss, 1983; Seki $\&$ Abe, 1985). Also, a qualitative difference occurs between the equine and carnivoran spleen. In fact, the capsule comprises two layers: the outer one is thin, containing tissues similar to that of non-mammalian spleens. The inner layer is thick and collagenous, comprised of elastic fibers and leiomyocytes. Concerning Artiodactyla, detailed description are available for the spleen of Alces alces (Blumenthal, 1952), Cervus elaphus, Capreolus capreolus (Hartwig \& Hartwig, 1975),
Bos taurus (Seki \& Abe, 1985), Bubalus bubalis (Mishra \& Verma, 2004), Ovis aries, Capra hircus (Tischendorf, 1969), Camelus dromedarius (Zidan et al., 2000), Camelus bactrianus (Abe et al., 1999), Hippopotamus amphibius (Tischendorf, 1958) and Sus scrofa (Seki \& Abe, 1985). In Artiodactyla, but also in Elephas maximus (Tischendorf, 1953), the spleen is covered by a bilayered capsule like in Equus. However, the degree of muscularization is even higher, due to the presence of an extensive network of smooth muscle cells in the red pulp. Thus, while the differences between the splenic functional morphology of Artiodactyla and Perissodactyla are mainly quantitative, the difference between these two Orders, on one side, and Carnivora, on the other, is qualitative.

The Grandorder of Ungulata is composed by Perissodactyla, Artiodactyla, Proboscidea, Tubulidentata, Hyracoidea, Cetacea and Sirenia (McKenna \& Bell, 1997). As explained, the spleens of the first three orders are highly specialized for blood storage, while those of the last two do not accumulate blood (Blessing et al., 1972). No data are available for Tubulidentata in the literature. Hyracoidea, instead, show a blood-storing spleen, but still with a mono-layered capsule (Hartwig \& Hartwig, 1985).

The xenarthran spleen. Xenarthra are commonly known as Edentates and they diverged from other Placentalia very early (McKenna \& Bell, 1997). The pres- 
ence of plesiomorphic features in their spleen, such as hemopoiesis or trilobed shape, is in accordance to their phylogenetically basal position. Apart from this, it is striking to note that they developed a type of spleen specialized to store blood similar to the ungulate one. A bi-layered capsule and the presence of a wide muscular network in the pulp cords have been reported in all the species studied until now: Myrmecophaga tridactyla, Tamandua tetradactyla, Choloepus hoffmanni, Cabassous unicinctus, Chaetophractus villosus, Euphractus sexcinctus (Claussen, 1969), Dasypus novemcinctus (Hayes, 1968), Dasypus hybridus (Galindezet al., 2000), Zaedyus pichiy (Claussen, 1969; Galindez et al., 2003).

\section{Conclusions}

In mammalian spleens, the white pulp (which reaches the highest degree of specialization among the whole vertebrates) retains the same main morphofunctional characteristics in all the Orders. Apart from Monotremata, Insectivora, Scandentia and Cetacea, which show a primitive splenic type distinguished by a closed circulation (Tanaka, 1994), the red pulp shows an evolutionary trend toward specialization in all the orders. One pathway is toward a defensive type ("Abwehrmilz"), proper of Primates and Rodentia, characterized by the presence of specialized, widespread and anastomosing venous vessels: the pulp sinuses. In this case, the red pulp is not predominant in comparison to the white pulp. The other pathway is in the direction of a storage type ("Speichermilz"), with a vast red pulp and a strong contractility (Fig. 1). However, it should be noted that some species owning a spleen with blood-storing properties, also show pulp sinuses. This is the case of species belonging to: Carnivora of the Arctoid branch (Canidae, Mustelidae, Procyonidae and Ursidae), excluding Pinnipedia; Artiodactyla, excluding Cervidae; Proboscidea and some Xenarthra. This has led to some confusion in the past. Nevertheless, it should be clear that the belonging to the blood-storing splenic type does not depend on the presence or absence of the pulp sinuses. Instead, it is due to storage volume and contractility.

While the high specialization of the immune function of the spleen is a common character of all mammals (including monotremes and marsupials), the development of the blood-storing properties reflects ecological pressures on the evolutionary process. Probably, a spleen that stores blood represented an advantage for Proboscidea, Artiodactyla and Perissodactyla to escape predation. At the same manner, it results useful to Carnivora for the opposite reason, i.e. to run after the prey. Among them, Pinnipedia show the higher portion of blood that can be stored in the spleen because of their diving habit. On the contrary, Cetacea own a primitive type of spleen, with a decisively small relative size: the ability to store blood in this organ is absent. Hartwig \& Hartwig (1985) explained this by the fact that Cetacea have no natural predators. However, it should be noted that in this Order the Retia Mirabilia perform the bloodstoring function. In Chiroptera, instead, the needs induced by the fatigue (due to the flight) are satisfied by higher specific oxygen uptake enabled by larger hearts and larger blood oxygen capacities (Jurgens et al., 1981). All these observations show, not only that different ecological demands led to different morphologies of an organ (in this case, the spleen), but also that the same demand led to tissue specialization speciesspecific. Finally, it must be mentioned that also Xenarthra show blood-storing spleens. While this is probably related to the fossorial habit of Cingulata (Dasypodidae), the reason for this characteristic in Pilosa (Myrmecophagidae, Megalonychidae and Bradypodidae) remains unclear.

Therefore, knowledge of the differences between the splenic types is not only useful in the field of comparative physiology, but it may also provide some helpful indications in the study of mammalian evolution.

\section{References}

Abe M., Takehana K., Iwasa K. \& Hiraga T. 1989. Scanning electron microscopic studies on the red pulp of the mink spleen // Japan Journal of Veterinary Science. Vol.51. P.775-781.

Abe M., Eerdunchaolu, Kobayashi A. \& Takehana K. 1999. Fine structure of the Bactrian camel (Camelus bactrianus) spleen // Journal of the Rakuno Gakuen University. Vol.24. P.45-53 [in Japanese].

Alexandre-Pires G., Pais D. \& Esperança Pina J.A. 2003. Intermediary spleen microvasculature in Canis familiaris - Morphological evidences of a closed and open type / / Anatomia Histologia Embryologia. Vol.32. P.263-270.

Blessing M., Ligensa K. \& Winner R. 1972. Zur Morphologie der Milz einiger im Wasser lebender Säugetiere // Zeitschrift wissenschaft Zooloogie. Vol.184. No.1-2. P.164-204.

Blumenthal I. 1952. Die Milz des Elches (Alces alces L.) // Zeitschrift Mikroskopische Anatomie Forschung. Vol.58. No.2. P.230-255.

Cabanac A.J., Messelt E.B., Folkow L.P. \& Blix A.S. 1999. The structure and blood-storing function of the spleen of the hooded seal (Cystophora cristata) // Journal of Zoology. Vol.248. No.1. P.75-81.

Claussen C.P. 1969. Vergleichende Untersuchungen zur makroskopischen und mikroskopischen Anatomie der Milzen einiger Edentata // Zeitschrift wissenschaft Zooloogie. Vol.179. P.333-424.

Galindez E.J., Codon S.M. \& Casanave E.B. 2000. Spleen of Dasypus hybridus (Mammalia, Dasypodidae): a light and electron microscopic study // Anatomical Record. Vol.258. P.286-291.

Galindez E.J., Estecondo S. \& Casanave E.B. 2003. The spleen of Zaedyus pichiy, (Mammalia, Dasypodidae): a light and electron microscopic study // Anatomia Histologia Embryologia. Vol.32. P.194-199.

Groom A.C., Schmidt E.E. \& MacDonald I.C. 1991. Microcirculatory pathways and blood flow in spleen: new 
insights from washout kinetics, corrosion casts, and quantitative intravital videomicroscopy // Scanning Microscopy. Vol.5. No.1. P.159-174.

Hartwig H. \& Hartwig H.G. 1975. Über die Milz der Cervidae (Gray, 1821). Quantitativ-morphologische Untersuchungen an Milzen des Rothirsches (Cervus elaphus L., 1785) und des Rehes (Capreolus capreolus L., 1758) // Gegenbaurs Morphologische Jahrbuch. Vol.121. No.6. P.669697.

Hartwig H. \& Hartwig H.G. 1985. Structural characteristics of the mammalian spleen indicating storage and release of red blood cells. Aspects of evolutionary and environmental demands // Experientia. Vol.41. P.159-163.

Hataba Y. \& Suzuki T. 1989. Scanning electron microscopic study of the red pulp of ferret spleen // Journal of Electron Microscopy. Vol.38. No.3. P.190-200.

Hayes T.G. \& Eglitis J.A. 1967. The microscopic structure of the adult Raccoon (Procyon lotor) and Woodchuck (Marmota monax) spleens // Journal of Morphology. Vol.121. P.47-54.

Hayes T.G. 1968. Electron and light microscopic observations of the armadillo (Dasypus novemcinctus mexicanus) spleen // Anatomical Record. Vol.160. P.473.

Jurgens K.D., Bartels H. \& Bartels R. 1981. Blood oxygen transport and organ weights of small bats and small nonflying mammals // Respiration Physiology. Vol.45. No.3. P.243-260

McKenna M.C. \& Bell S.K. 1997. Classification of Mammals above the Species Level. New York: Columbia University Press.

Mishra B.K. \& Verma P.K. 2004. Capsule and trabeculae of the spleen: a comparative histology // Journal of the Anatomical Society of India. Vol.53. No.1. P.59-60.

Schumacher U. \& Welsch U. 1987. Histological, histochemical, and fine structural observations on the spleen of seals // American Journal of Anatomy. Vol.179. No.4. P.356-368.
Seki A. \& Abe M. 1985. Scanning electron microscopic studies on the microvascular system of the spleen in the rat, cat, dog, pig, horse and cow // Japan Journal of Veterinary Science. Vol.47. P.237-249.

Stewardson C.L., Hemsley S., Meyer M.A., Canfield P.J. \& Macdonald J.H. 1999. Gross and microscopic visceral anatomy of the male Cape fur seal, Arctocephalus pusillus pusillus (Pinnipedia: Otariidae), with reference to organ size and growth // Journal of Anatomy. Vol.195. No.2. P.235-255

Tablin F. \& Weiss L. 1983. The equine spleen: an electron microscopic analysis // American Journal of Anatomy. Vol.166. P.393-416.

Tanaka Y. 1994. Microscopy of vascular architecture and arteriovenous communications in the spleen of two odontocetes // Journal of Morphology. Vol.221. P.211-233.

Tischendorf F. 1953. Über die Elefantenmilz // Zeitschrift fur Anatomie und Entwicklungsgeschichte. Vol.116. No.8. P.577-590.

Tischendorf F. 1956. Milz // Helmcke J.G. \& von Lengerken H. (eds.). Handbuch der Zoologie. Vol.8. No.5(2). Berlin: de Gruyter \& Co. P.1-32.

Tischendorf F. 1958. Über die Hippopotamidenmilz // Zeitschrift Mikroskopische Anatomie Forschung. Vol.64. No.2. P.228-257.

Tischendorf F. 1969. Die Milz // Möllendorff W. \& Bargmann W. (eds.). Handbuch der mikroskopische Anatomie der Menschen. Vol.6. No.6. Berlin: Springer-Verlag. P.1-968.

Zhang Y., Zhang L. \& Feng G. 1997. Light and electron microscopic observation in black bear spleen // Chinese Journal of Zoology. Vol.32. P.29-30 [in Chinese].

Zidan M., Kassem A., Dougbag A., El Ghazzawi E., Abd El Aziz M. \& Pabst R. 2000. The spleen of the one humped camel (Camelus dromedarius) has a unique histological structure // Journal of Anatomy. Vol.196. No.3. P.425432. 